\title{
The anticoagulants ASIS or APC do not protect against renal ischemia/ reperfusion injury
}

\author{
Sarah T.B.G. Loubele ${ }^{1}$, C. Arnold Spek ${ }^{2}$, Peter Leenders ${ }^{3}$, Robert A. Matthijsen ${ }^{4}$, Wim A. Buurman ${ }^{4}$, \\ Carine J. Peutz-Kootstra ${ }^{5}$, Henri M.H. Spronk ${ }^{* 1}$, and Hugo ten Cate ${ }^{1}$ \\ ${ }^{1}$ Department of Internal Medicine, Laboratory for Clinical Thrombosis and Haemostasis, Cardiovascular Research Institute \\ Maastricht, Maastricht University Medical Center+, Maastricht, The Netherlands \\ ${ }^{2}$ Center for Experimental and Molecular Medicine, Academic Medical Center, Amsterdam, The Netherlands \\ ${ }^{3}$ Department of Pharmacology, Cardiovascular Research Institute Maastricht, Maastricht University Medical Center+, \\ Maastricht, The Netherlands \\ ${ }^{4}$ Department of General Surgery, School for Nutrition \& Metabolism (NUTRIM), Maastricht University Medical Center+, \\ Maastricht, The Netherlands \\ ${ }^{5}$ Department of Pathology, Maastricht University Medical Center+, Maastricht, The Netherlands \\ *Corresponding author's e-mail address: henri.spronk@maastrichtuniversity.nl
}

Published online: June 12, 2014 (version 1)

Cite as: S.T.B.G. Loubele et al., ScienceOpen Research 2014 (DOI: 10.14293/A2199-1006.01.SOR-MED.YXBIK.v1)

Reviewing status: Please note that this article is under continuous review. For the current reviewing status and the latest referee's comments please click here or scan the QR code at the end of this article.

Keywords: Renal ischemia/reperfusion, Anticoagulants, Inflammation, Apoptosis

\begin{abstract}
Renal ischemia/reperfusion (I/R) injury is the main cause of acute renal failure. The severity of injury is determined by endothelial damage as well as inflammatory and apoptotic processes. The anticoagulants active site inhibited factor VIIa (ASIS) and activated protein C (APC) are besides their anticoagulant function also known for their cytoprotective properties. In this study the effect of ASIS and APC was assessed on renal I/R injury and this in relation to inflammation and apoptosis. Our results showed no effect of ASIS or APC on renal injury as determined by histopathological scoring as well as by blood urea nitrogen (BUN) and creatinine levels. Furthermore, no effect on fibrin staining was detected but ASIS did reduce tissue factor activity levels after a 2-hr reperfusion period. Neither ASIS nor APC administration influenced overall inflammation markers, although some inflammatory effects of ASIS on interleukin (IL)-1 $\beta$ and tumor necrosis factor (TNF)- $\alpha$ were detectable after $2 \mathrm{hr}$ of reperfusion. Finally, neither APC nor ASIS had an influence on cell signaling pathways or on the number of apoptotic cells within the kidneys. From this study we can conclude that the anticoagulants ASIS and APC do not have protective effects in renal I/R injury in the experimental setup as used in this study which is in contrast to the protective effects of these anticoagulants in other models of I/R.
\end{abstract}

\begin{tabular}{|c|c|}
\hline What is known on this topic? & What this paper adds? \\
\hline $\begin{array}{l}\text { - Several anticoagulants show } \\
\text { both protective as well as non- } \\
\text { protective effects on renal I/R } \\
\text { injury. } \\
\text { - APC is protective in a rat } \\
\text { model of renal I/R injury via } \\
\text { reduced inflammation. } \\
\text { - ASIS and APC are protective in } \\
\text { several I/R injury models. }\end{array}$ & $\begin{array}{l}\text { - First mouse renal I/R injury } \\
\text { model in which ASIS and APC } \\
\text { are used as an intervention. } \\
\text { - No effect of APC or ASIS in } \\
\text { this model of renal I/R injury } \\
\text { in which the left kidney is } \\
\text { clamped and the right one is } \\
\text { removed after induction of } \\
\text { reperfusion. } \\
\text { - No effect of APC on inflam- } \\
\text { mation, apoptosis, and renal } \\
\text { function. }\end{array}$ \\
\hline
\end{tabular}

\section{INTRODUCTION}

Renal ischemia/reperfusion (I/R) injury contributes in a large extent to kidney failure after organ transplantation [1]. The molecular mechanisms involved in the development of renal I/R injury are not yet completely understood but involve the generation of reactive oxygen species and an inflammatory response with the release of cytokines and the expression of adhesion molecules [2]. Furthermore, the process of renal I/R leads to cell death either via necrosis due to a loss of ATP or apoptosis due to cell signaling involved mechanisms [3]. Whether the process of inflammation is involved in the development of cell death or the other way around still remains a 
matter of debate [4-6]. Anticoagulants may exert, beside their anticoagulant function, also cell protective properties. Activated protein C (APC) is a natural anticoagulant which in a clinical setting is used in the treatment of severe sepsis (PROWESS trial) [7]. Besides its anticoagulant properties, APC exerts cytoprotective functions via inhibition of inflammation, prevention of apoptosis, and protection of the endothelial barrier function [8]. Administration of APC has shown to limit organ damage in several animal models including an ischemic stroke model, a lung injury model, and a spinal cord ischemia model [9-12]. A recent study revealed a protective effect of APC against diabetic nephropathy. In this study mice over expressing human APC were shown to have less nephropathy in long-term diabetes due to a modulating effect on apoptosis of endothelial cells and podocytes [13]. Furthermore, APC was shown to be protective in a rat renal I/R model [14]. The anticoagulant active-site inhibited factor VIIa (ASIS) is also known for its cytoprotective properties as it reduces myocardial I/R injury via inhibition of inflammation $[15,16]$.

Hence, we hypothesized that administration of APC or ASIS would protect against renal I/R injury via apoptosis and inflammation-regulated mechanisms. In the current study we used a mouse model for renal I/R injury in which either a 1$\mathrm{hr}$ ischemia time was used followed by $2 \mathrm{hr}$ of reperfusion or a 40 -min ischemia time followed by 2 or $24 \mathrm{hr}$ of reperfusion. In contrast to previous studies [14, 17-19], in our experimental model only one kidney was clamped instead of two, while reperfusion of the clamped kidney was allowed after removal of the contra lateral kidney. This approach is considered to be a good model for the clinical situation of ischemia reperfusion injury in a single transplanted kidney, which is one of the critical conditions related to renal I/R damage [4]. We investigated the effects of mouse APC and ASIS on early renal I/R injury, particularly related to anticoagulant, antiinflammatory and anti-apoptotic mechanisms.

\section{MATERIALS AND METHODS Experimental procedure}

All animal experiments were approved by the Animal Ethics Committee of the Maastricht University. Male C57Black/6 mice of 8 weeks old and around $25 \mathrm{~g}$ were purchased from Charles River Laboratories (Sulzfeld, Germany) and were housed under normal conditions: temperature was kept constant at $20-24^{\circ} \mathrm{C}$ and food and water were provided ad libitum. Mice were anesthetized with isoflurane (induced with 3 $4 \%$ and maintained with $1.5-2.5 \%$ ) and were ventilated (frequency: $210 / \mathrm{min}$, volume: $250 \mu \mathrm{l}$ ). Thirty minutes before the procedure, buprenorphine (Temgesic, $0.1 \mathrm{mg} / \mathrm{kg}$ ) was given subcutaneously. Body temperature was assessed using a rectal probe and was kept constant at $37^{\circ} \mathrm{C}$ using a heath pad. Ischemia was induced by placing a clamp to the left renal pedicle either for $40 \mathrm{~min}$ or for $1 \mathrm{hr}$. After removal of the clamp, the collateral kidney was removed. The animals were sacrificed after $2 \mathrm{hr}$ (for the 40-min and the 1-hr ischemia period) of after $24 \mathrm{hr}$ (only for the $40 \mathrm{~min}$ ischemia period).
Animals undergoing a 1-hr ischemia period did not survive a 24-hr reperfusion period; hence this group was not included in the study. Mouse APC $(0.4 \mathrm{mg} / \mathrm{kg})$, human ASIS $(10 \mathrm{mg} /$ $\mathrm{kg})$, or placebo $(0.9 \% \mathrm{NaCl})$ were administered 2 min before induction of reperfusion and 15 min after induction of reperfusion. In an additional experiment mouse APC was administered in a $0.4-\mathrm{mg} / \mathrm{kg}$ or a $1-\mathrm{mg} / \mathrm{kg}$ dose, $5 \mathrm{~min}$ after the beginning of ischemia, and 5 min after the induction of reperfusion. The rationale for the chosen doses of APC is based on a study by Cheng et al. [20] where APC treatment was shown to be effective and for ASIS the optimal dose was determined by a dose-finding study (data not shown). Furthermore, the systemic anticoagulant activity was assessed by means of a thrombin generation assay in which the doses used revealed reduced thrombin levels when added to mouse plasma (data not shown). After the mentioned reperfusion time, sodium citrate $(3.2 \%)$ was injected directly into the vena cava, blood was drawn from the vena cava, and plasma was collected as described previously [21].

\section{Tissue collection}

After sacrificing, two groups were obtained for further analysis: one group for RNA and protein analysis $(n=6)$ and the other group for paraffin tissue sections $(n=10)$. After blood collection the left kidney was rinsed with $0.9 \% \mathrm{NaCl}$ and subsequently removed. The kidneys were either frozen in liquid nitrogen for protein and RNA analysis or stored in paraformaldehyde (4\%) for paraffin tissue sections. The left kidneys were dry frozen and pulverized. For protein analysis, $10 \mathrm{mg}$ of the powdered tissue was dissolved in $28 \mathrm{mM}$ of n-octyl- $\beta$ D-glucopyranoside (Sigma, St. Louis, MO, USA) to disintegrate the cell membranes and to release the protein content in the solution. After centrifugation (14,000 rpm, $10 \mathrm{~min}$ at RT), total protein concentrations were determined in the supernatant using the Bio-Rad Dc Protein Assay (Bio-Rad Laboratories, Veenendaal, the Netherlands). All samples were diluted to a total protein concentration of $1 \mathrm{mg} / \mathrm{ml}$ protein. Ten milligram of tissue powder was dissolved in $1 \mathrm{ml}$ of tri reagent (Sigma, St. Louis, MO, USA) for total RNA isolation and RNA was further isolated according the manufacturer's instructions.

\section{Renal function}

In mice that underwent $24 \mathrm{hr}$ of reperfusion blood urea nitrogen (BUN) and creatinine levels were determined in plasma with a Beckman/Coulter Synchron LX-20.

\section{Renal histology}

To determine renal injury, paraffin sections $(5 \mu \mathrm{m})$ were stained with Periodic acid-Schiff-diastase (PAS-D). A 5-point scale scoring system was used to determine a histopathological score as described by Leemans et al. [22]. Ten fields on the corticomedullary junction within one section were scored 
for tubular dilatation, necrosis, cast deposition, and brush border loss using a $20 \times$ magnification.

\section{Tissue factor activity}

Tissue factor (TF) activity was determined in the $1-\mathrm{mg} / \mathrm{ml}$ protein sample dilutions using a homemade $\mathrm{TF}$ activity assay. In brief, samples were incubated for $10 \mathrm{~min}$ at $37^{\circ} \mathrm{C}$ with a mixture consisting of $2.8 \mathrm{nM}$ recombinant FVIIa (Novo, Bagsværd, Denmark), $278 \mathrm{nM}$ bovine FX, $10 \mathrm{mM} \mathrm{Ca}^{2+}$, and 40 $\mu \mathrm{M}$ 20/80 phosphatidylserine/phosphatidylcholine vesicles in tris buffer (15.4 M Tris, $5.7 \mathrm{M} \mathrm{NaCl}, \mathrm{pH}=7.35)$. Chromogenic substrate S2765 (BIOMAT B.V., Maastricht, the Netherlands) was added and the amount of factor Xa formed was measured kinetically at $405 \mathrm{~nm}$ for $10 \mathrm{~min}$. Innovin (Dade Behring, Deerfield, IL, USA) was used as reference and control points with a reference curve ranging from 0.39 to $6 \mathrm{pM}$.

\section{PAI-1 antigen}

Total PAI-1 antigen levels were determined in tissue homogenates $(1 \mathrm{mg} / \mathrm{ml}$ protein content) according to the manufacturer's instructions (Innovative Research, Novi, MI, USA).

\section{Microwave phosphotungstic acid hematoxylin (PTAH) staining}

Tissues were stained for fibrin using the PTAH staining kit (American Master Tech Scientific Inc., CA, USA). All experiments were performed according to the manufacturer's instructions. Tissues were scored using a 3-point scoring system: 1 - mild fibrin deposition in $<20 \%$ of the cortex; 2 - moderate fibrin deposition in $20-50 \%$ of the cortex; and 3 - high amount of fibrin deposition in $>50 \%$ of the cortex.

\section{Interleukin-6, tumor necrosis factor, and IL-1 $\beta$ antigen}

Interleukin-6 (IL-6), tumor necrosis factor (TNF- $\alpha$ ), and IL-1 $\beta$ antigen levels were determined in tissue homogenates containing $1 \mathrm{mg} / \mathrm{ml}$ protein using an ELISA reagent set. All analyses were performed according to the manufacturer's manual (eBioscience, San Diego, CA, USA).

\section{Myeloperoxidase}

Mouse myeloperoxidase (MPO) was determined in tissue homogenates containing $1 \mathrm{mg} / \mathrm{ml}$ protein using an ELISA kit. All analyses were performed according to the manufacturer's manual (Hycult biotechnology b.v., Uden, the Netherlands).

\section{Multiplex ligation-dependent probe amplification (MLPA)}

Coagulation, inflammation, cell signaling, and apoptosis-related gene expression levels were determined in isolated RNA of the mouse kidneys ( $n=6$ per group). As many as $50 \mathrm{ng} / \mu \mathrm{l}$ RNA was analyzed according to the method described previously by Spek et al. [23]. Several genes were analyzed (cell signaling: CD14, toll-like receptor [TLR]-2, TLR-4, IL-1 receptor-associated kinase (IRAK)-1, IRAK-3, IкB $\alpha$, and protease activated receptor-1 [PAR-1]; coagulation: TF, tissue factor pathway inhibitor [TFPI], plasminogen activator inhibitor-1 [PAI-1], urokinase-type plasminogen activator receptor [uPAR], tissue-type plasminogen activator receptor [t-PA], and protein $C$ receptor; inflammation: IL-6, IL-4, IL-10, IL-1 $\beta$, TNF- $\alpha$, interferon- $\gamma$, hypoxia-inducible factor- $1 \alpha$, ICAM-1, macrophage inflammatory protein- $1 \alpha, \mathrm{CxCl} 1, \mathrm{CCl} 3$, and eNOS). Only the genes that showed detectable expression levels are depicted in the results.

\section{Apoptosis}

Mouse kidney paraffin sections were stained for DNA laddering using the ApopTag Plus Peroxidase In Situ Apoptosis Detection Kit (Chemicon, Billerica, USA) and the In Situ Cell Death Detection Kit TMR red (Roch Diagnostics, Indianapolis, USA). Sections were stained according the manufacturer's manual. Analyses of all sections were done blinded for treatment allocation (APC, placebo, or sham). The amount of apoptosis was estimated by counting the number of cells in three fields within the infarcted area (40× magnification). Data are represented as the number of positive cells per surface area.

\section{Statistical analyses}

Data analysis was performed with Prism for Windows, version 5.00 (GraphPad Software Inc., San Diego, CA, USA). Values are means \pm SEM. Differences between groups were tested using a Mann-Whitney $U$-test and $P$ values $<0.05$ were considered statistically significant.

\section{RESULTS \\ Renal function}

Renal function neither improved upon APC nor upon ASIS administration, as both BUN (Figure 1A) and creatinine (Figure 1B) plasma levels remained equal after APC (50.4 \pm $1.6 \mathrm{mmol} / \mathrm{l}$ and $186.4 \pm 4.1 \mu \mathrm{mol} / \mathrm{l}$, respectively) or ASIS administration 2 min before induction of reperfusion and 15 min after induction of reperfusion $(53.1 \pm 1.5 \mathrm{mmol} / \mathrm{l}$ and $193.5 \pm 4.6 \mu \mathrm{mol} / \mathrm{l})$ compared to placebo administration (54.0 $\pm 1.3 \mathrm{mmol} / \mathrm{l}$ and $194.6 \pm 3.5 \mu \mathrm{mol} / \mathrm{l}$, respectively). In addition, APC was administered at the beginning of the ischemic period and at the beginning of the reperfusion period in both a $0.4-\mathrm{mg} / \mathrm{kg}$ and a $1-\mathrm{mg} / \mathrm{kg}$ dose. BUN (Figure 1C) as well as creatinine (Figure 1D) levels were not influenced after the administration of APC early in the ischemia period and with a varying dose.

\section{Renal histology}

Paraffin sections were scored for tubular dilatation, cast deposition, brush border loss, and necrosis after which an 

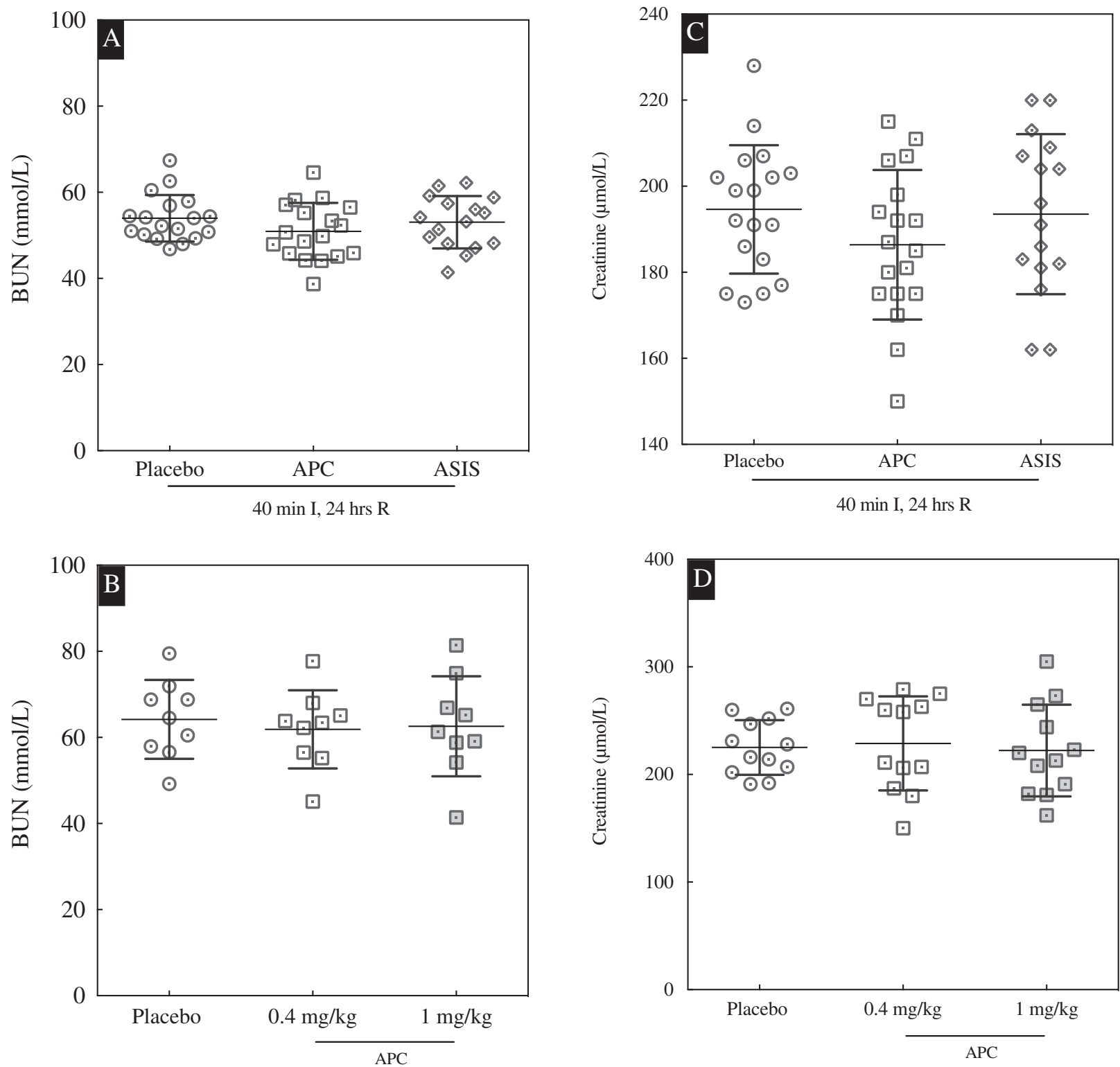

Figure 1. Panel A: BUN levels and Panel B: creatinine levels did not differ upon APC nor upon ASIS administration 2 min before induction of reperfusion and $15 \mathrm{~min}$ after induction of reperfusion compared to placebo after $40 \mathrm{~min}$ of ischemia followed by $24 \mathrm{hr}$ of reperfusion. Administration of APC in a higher dose and at an earlier time point in the ischemic phase did not reveal changes in Panel C: BUN or Panel D: creatinine levels compared to placebo. Values are mean $\pm \mathrm{SEM}, n=18$ per group.

average histopathological score was obtained for a total of 10 mice per group. APC administration did not improve the score after $1 \mathrm{hr}$ of ischemia and $2 \mathrm{hr}$ of reperfusion compared to placebo administration (Figure 2A). Administration of ASIS revealed a decreased histopathological score compared to the placebo animals but the results were not significantly different. Renal injury increased after $24 \mathrm{hr}$ of reperfusion compared to $2 \mathrm{hr}$ of reperfusion after a 40-min ischemia period. Administration of APC or ASIS did however not decrease renal injury as the histopathological score of both placebo and APC- or ASIS-treated animals remained equal after $2 \mathrm{hr}$ as well as $24 \mathrm{hr}$ of reperfusion (Figure 2B). Administration of APC in a higher dose and at a different time point during ischemia also revealed no effect on the histopathological score (data not shown).

\section{Coagulation parameters}

TF activity levels were increased after $40 \mathrm{~min}$ of ischemia and $24 \mathrm{hr}$ of reperfusion compared to sham animals and animals with a 2-hr reperfusion period. No differences could be detected upon APC administration compared to placebo after 

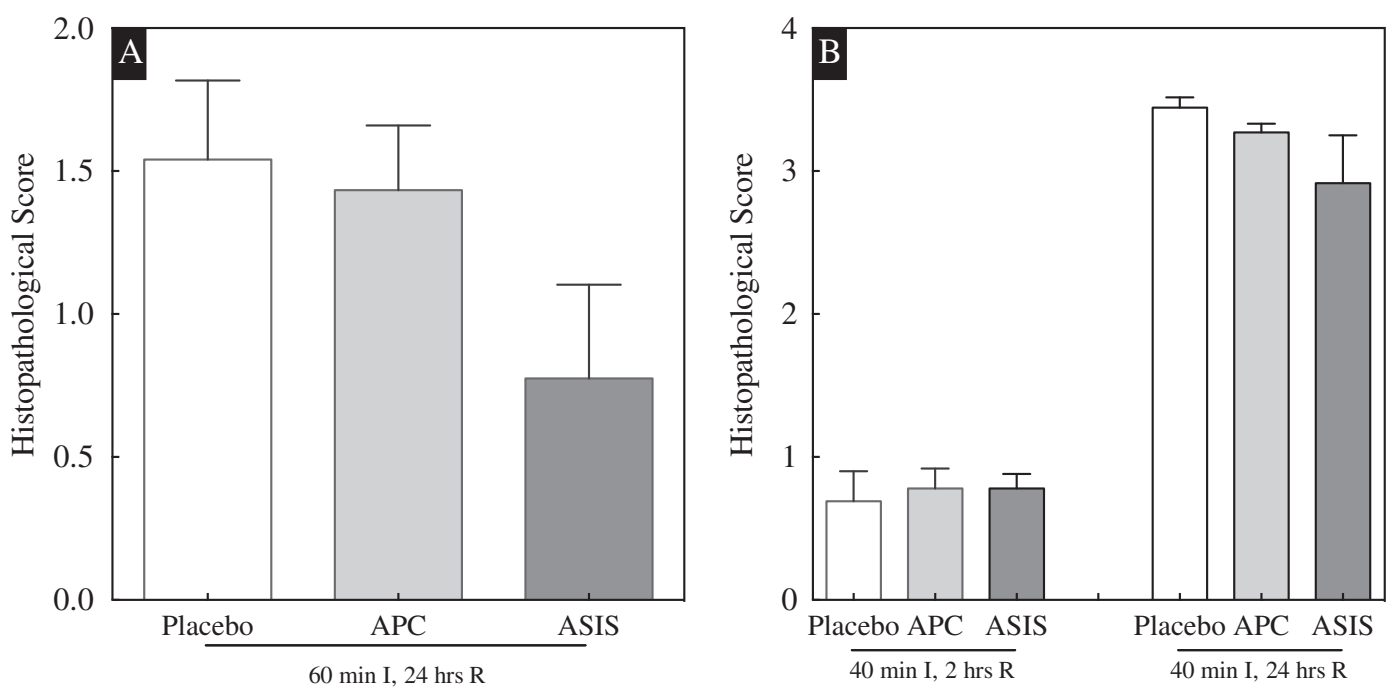

Figure 2. Panel A: histopathological scoring did not reveal an influence of APC on renal injury after $1 \mathrm{hr}$ of I followed by $2 \mathrm{hr}$ of $\mathrm{R}$ but revealed a trend toward a decreased score upon ASIS administration compared to placebo. Panel B: APC nor ASIS administration influenced the histopathological score after $40 \mathrm{~min}$ of I followed by 2 or $24 \mathrm{hr}$ of R. Values are mean \pm SEM, $n=10,{ }^{*} p<0.05$.

varying ischemia and reperfusion times (Figure 3A). Administration of ASIS did however decrease TF activity levels after a 2-hr reperfusion period both for a 40-min and a 1-hr ischemia period. No differences in TF activity were visible after a 24-hr reperfusion period. PAI antigen levels were assessed after $1 \mathrm{hr}$ of ischemia and $2 \mathrm{hr}$ of reperfusion and revealed increased PAI-1 levels upon I/R compared to sham animals. Administration of APC or ASIS did however not influence PAI-1 antigen levels (data not shown). Tissue scoring for fibrin deposition revealed an increase in fibrin deposition after $24 \mathrm{hr}$ of ischemia compared to $2 \mathrm{hr}$ of reperfusion. Administration of neither APC nor ASIS influenced fibrin deposition in the cortex of the kidneys (Figure 3B).

\section{Inflammation markers}

IL-6, IL-1 $\beta$, and TNF- $\alpha$ levels were determined in tissue homogenates of the left kidneys. IL-6 levels increased upon I/R after both a 1-hr reperfusion and a 40-min reperfusion time (Figure 4A-C). Neither APC nor ASIS administration revealed an anti-inflammatory effect in the ischemic kidneys and even increased IL-6 levels after both a 1-hr and a 40-min ischemic period followed by a 2-hr reperfusion time (Figure $4 \mathrm{~A}$ and 4B). I/R increased IL-1 $\beta$ levels compared to sham animals for both the 1-hr and the 40-min ischemia period. APC administration did not influence IL-1 $\beta$ levels for neither of the varying I/R times. Administration of ASIS did however decrease IL-1 $\beta$ after a 1-hr ischemia and a 2-hr reperfusion period
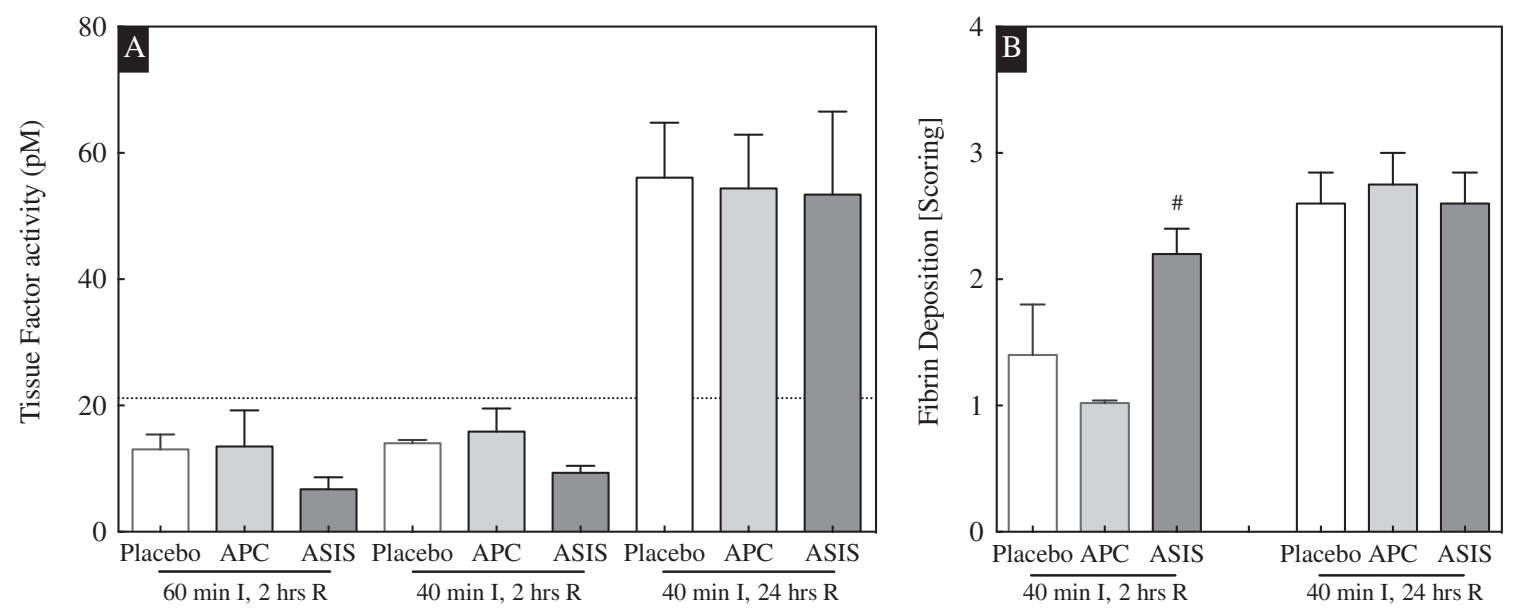

Figure 3. Panel A: TF activity levels decreased after ASIS administration but were not influenced upon APC administration. Panel B: fibrin deposition increased after $24 \mathrm{hr}$ of reperfusion but was not influenced upon APC or ASIS administration. Values are mean \pm SEM, $n=10$, \# ASIS vs. placebo $p<0.05$. 
compared to placebo (Figure 4A). TNF- $\alpha$ levels increased upon I/R compared to the sham group. TNF- $\alpha$ levels were not decreased upon APC administration after $2 \mathrm{hr}$ or reperfusion with both a 1-hr and a 40-min ischemic time. APC did however decrease TNF- $\alpha$ levels after a 40-min ischemic period followed by a 24-hr reperfusion phase. Administration of ASIS, on the other hand, decreased TNF- $\alpha$ levels after a 1-hr ischemia and a 2-hr reperfusion period but increased TNF- $\alpha$ levels after a 40-min ischemia and 2-hr reperfusion period compared to placebo (Figure 4A-C). MPO levels increased upon I/ $\mathrm{R}$ compared to sham animals. No downregulating effect of APC or ASIS administration could be detected, and administration of both APC and ASIS even increased MPO levels after a 1-hr ischemia and 2-hr reperfusion period compared to placebo administration (Figure 4A).

\section{MLPA analysis cell signaling, coagulation, and inflammation}

Analysis of cell signaling-related genes involved in the NF- $\kappa B$ pathway did not reveal an effect of APC or ASIS on this pathway as TLR-4, IRAK-1, and I $\kappa \mathrm{B} \alpha$ levels remained equal after APC or ASIS treatment compared to placebo administration (data not shown). PAR-1 expression levels increased after a 24-hr reperfusion period compared to a 2-hr reperfusion period and to nonischemic kidneys. However, no effect of APC or ASIS administration was detected on PAR-1 RNA expression levels (data not shown).

TF RNA expression levels were increased upon I/R compared to the sham animals showing the highest TF RNA levels after $24 \mathrm{hr}$ of reperfusion (Figure 5C). Administration of APC showed a trend toward decreased TF RNA levels, but the results were only significant after a 40 -min ischemia and a 2-hr reperfusion period. TF RNA levels were decreased after a 40-min ischemia and a 2-hr reperfusion period upon ASIS administration. PAI-1 RNA expression levels also increased upon I/R compared to the sham group and revealed increasing levels of PAI-1 after $24 \mathrm{hrs}$ of reperfusion (Figure $5 \mathrm{~A}-\mathrm{C}$ ).
APC nor ASIS administration did however influence PAI-1 expression levels. Inflammation markers IL-6 and IL-1 $\beta$ showed increased mRNA expression levels after I/R compared to sham animals. APC or ASIS administration showed no anti-inflammatory effect as APC as well as ASIS administration even increased IL- 6 and IL- $1 \beta$ levels compared to placebo administration after a 40-min ischemia period followed by $2 \mathrm{hr}$ of reperfusion (Figure 5B). A similar trend was observed after a 1-hr ischemia and 2-hr reperfusion period (Figure 5A). A small decrease in IL-6 and IL-1 $\beta$ levels was observed after a 40-min ischemia and a 24-hr reperfusion time but the results were not significant (Figure 5C).

\section{Apoptosis}

Kidney paraffin sections were stained for DNA Laddering. A representative picture is given in Figure 6A. Scoring of the sections by counting apoptotic cells per surface area within the corticomedullary junction did not reveal any statistically significant effects of ASIS or APC administration on DNA laddering. Furthermore, no differences in apoptosis levels were detectable between a 2-hr and a 24-hr reperfusion period (Figure 6B).

\section{DISCUSSION}

In this study we aimed to address the protective mechanisms of the anticoagulants APC and ASIS in a model of renal I/R injury, based on previously studied protective effects of such interventions in renal I/R injury but also in myocardial I/R and stroke.

Renal injury was evident in our model, as assessed by histopathological scoring for tubular dilatation, brush border loss, necrosis, and cast deposition showing increased renal injury after a prolonged reperfusion time of $24 \mathrm{hr}$ compared to $2 \mathrm{hr}$. This tubular injury is probably maximal after $24 \mathrm{hr}$ of reperfusion as previous studies have shown a recovery of tubular injury after a few days of reperfusion compared to 1 day of reperfusion $[22,24]$.
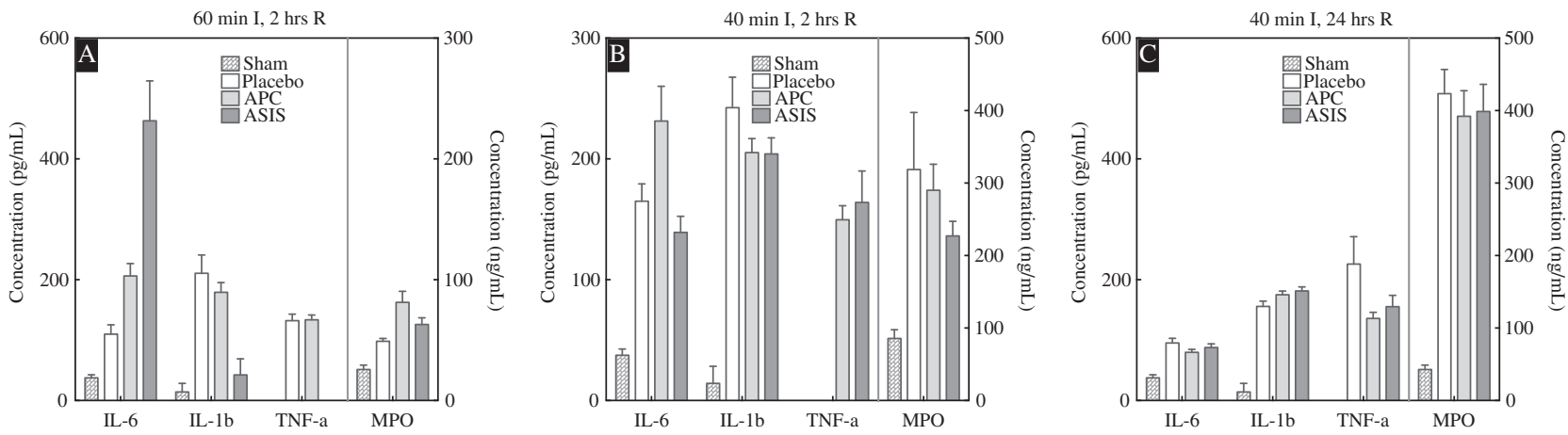

Figure 4. Effect of APC and ASIS on inflammatory markers after Panel A: $1 \mathrm{hr}$ of ischemia and $2 \mathrm{hr}$ of reperfusion, Panel B: 40 min of ischemia and $2 \mathrm{hr}$ of reperfusion, and Panel C: $40 \mathrm{~min}$ of ischemia and $24 \mathrm{hr}$ of reperfusion. Values are mean $\pm \mathrm{SEM}, n=6, *$ sham vs. placebo, \# ASIS vs. placebo, \$ APC vs. placebo, $p<0.05$. 

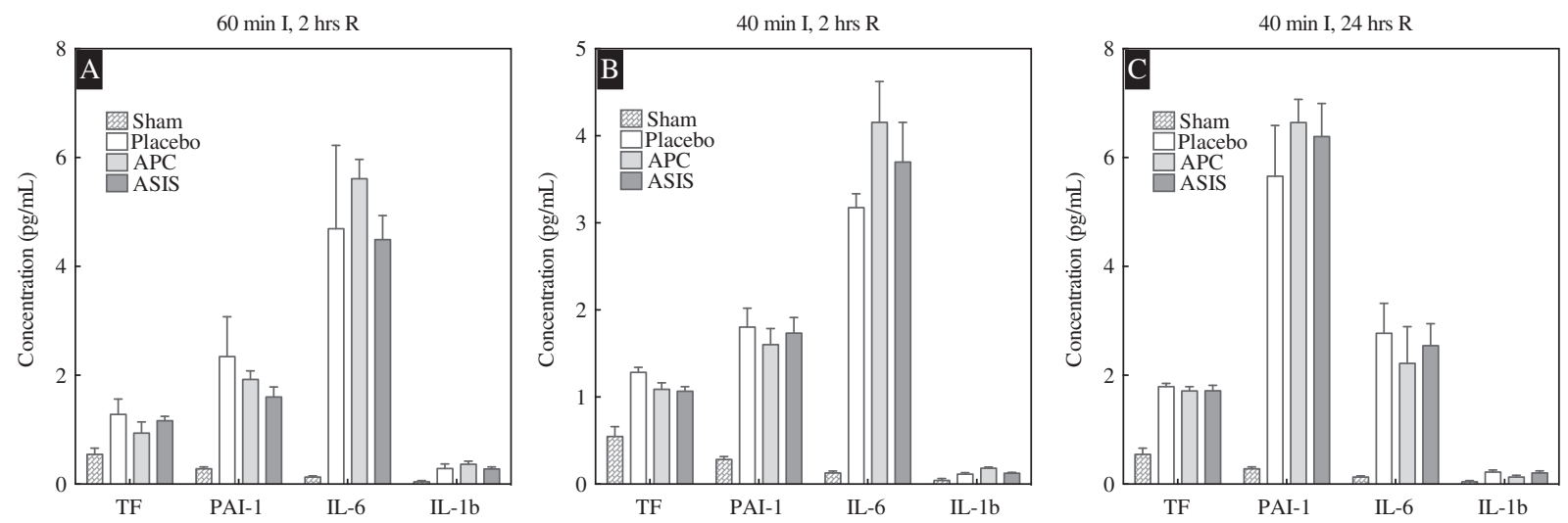

Figure 5. Effect of APC and ASIS on RNA expression level after Panel A: $1 \mathrm{hr}$ of ischemia and $2 \mathrm{hr}$ of reperfusion, Panel B: 40 min of ischemia and $2 \mathrm{hr}$ of reperfusion, and Panel C: $40 \mathrm{~min}$ of ischemia and $24 \mathrm{hr}$ of reperfusion. Values are mean \pm SEM, $n=6, *$ sham vs. placebo, \# ASIS vs. placebo, \$ APC vs. placebo, $p<0.05$.
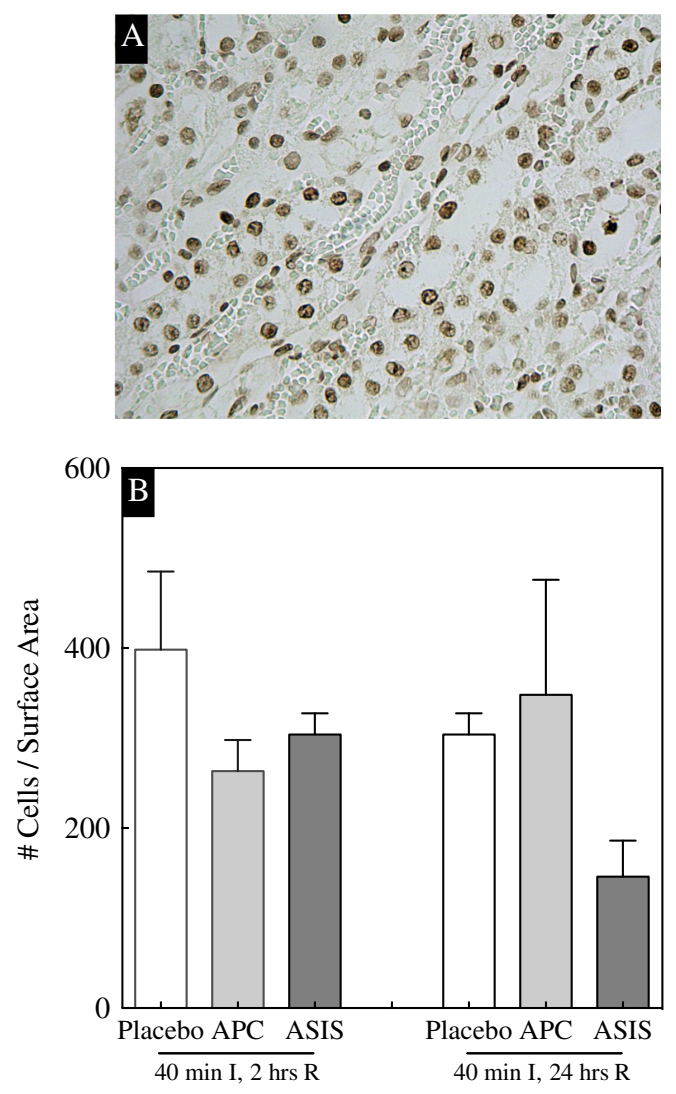

Figure 6. Panel A: representative picture of a TUNEL stained paraffin section. Apoptotic cells are shown in brown, the cell nuclei are depicted in green; 40× magnification. Panel B: slides were scored for the number of positive cells within 3 fields of the infarcted area using a $40 \times$ magnification. No difference in the number of apoptotic cells was observed upon ASIS or APC administration during both the ischemic and the reperfusion phase within the corticomedullary junction $(n=4)$.
In spite of the clearly evident renal injury, our study did not reveal any protective effects of APC or ASIS on renal I/R injury as indicated by BUN and creatinine levels, as well as histopathological scoring. Moreover, administration of APC at a different time point during ischemia or at an increased dose did not result in any measurable protective effects.

Renal I/R injury is of great importance in renal transplantation surgery and is an important cause of acute renal failure (ARF). Activation of the coagulation cascade is associated with this disease process as fibrin deposition in the microvasculature and tubuli of ischemic kidneys is observed [25, 26]. Activation of coagulation can via protease-activated receptors (PARs) in turn induce inflammatory pathways contributing to cell death. PAR-1, which is expressed in the kidney, can be activated by several coagulation proteases including FVIIa, FXa, and most importantly thrombin and APC [27, 28]. Several anticoagulants have been studied in injury models for their cytoprotective properties in addition to their anticoagulant functions [12-15] and a few of those were also investigated in kidney I/R models. The anticoagulant fondaparinux, as well as a nonanticoagulant synthetic pentasaccharide were protective against renal I/R injury as shown by an increased survival rate, reduced creatinine levels after $48 \mathrm{hr}$ of reperfusion, reduced cytokine levels, and decreased neutrophil accumulation compared to placebo administration [17, 29]. A rat kidney I/R model revealed a protective role for APC $(100 \mu \mathrm{g} /$ $\mathrm{kg}$ ) as BUN, creatinine, TNF- $\alpha$, IL- 6 , and MPO levels were decreased upon APC administration 30 min prior to ischemia, compared to placebo and this was most likely regulated via an inhibition of leukocyte activation [14]. Furthermore, administration of antithrombin reduced I/R-induced renal injury in rats [18]. Also, low TF mice ( $1 \%$ human $\mathrm{TF})$, as well as PAR-1 deficient mice, were protected against renal I/ $\mathrm{R}$ injury as demonstrated by reduced mortality rates, tubular injury, and neutrophil infiltration compared to wild-type 
(WT) mice [26]. Thrombin inhibition via melagatran administration, on the other hand, did not protect against renal I/R injury as shown via determination of the glomerular filtration rate and histological scoring of injury [19]. In a clinical setting, the presence of increased plasma levels of APC was associated with reduced neutrophil activation markers, a process which can be protective in renal transplantation surgery [30]. Based on published data as well as our own studies showing an effective reduction of I/R injury in the heart, associated with similar dose regimens of ASIS [16] and APC [31], we expected to find at least an indication of a protective effect in the renal I/R experiments. Surprisingly, our model did not reveal a protective role for the anticoagulants APC nor ASIS after a 2-hr or a 24-hr reperfusion period.

Besides the general indices of renal function we studied several mechanisms that may be related to cell injury upon I/R. Although the anticoagulant effects of ASIS and APC were shown in vitro (data not shown), net procoagulant activity was not attenuated by the interventions with APC and ASIS, as fibrin deposition was clearly increased after $24 \mathrm{hr}$ of reperfusion, but unaltered by ASIS or of APC administration. Furthermore, coagulation parameters including renal TF activity and mRNA levels were increased after $24 \mathrm{hr}$ of reperfusion compared to $2 \mathrm{hr}$. Administration of ASIS inhibited TF activity in the kidney, but TF levels remained equal upon APC administration. The lack of any protective effect of APC or ASIS on a long-term reperfusion period could in part be related to a lack of attenuating effect on tissue TF concentrations, taking into account that Sevastos et al. [26] showed that TF deficient mice were protected from renal failure and death.

Inflammation markers IL-6, IL-1 $\beta, \mathrm{TNF}-\alpha$, and MPO protein levels as well as IL- 6 and IL- $1 \beta$ mRNA levels were upregulated upon I/R injury. A number of anti-inflammatory effects of ASIS and APC were observed, indicated by decreased IL-1 $\beta$ and TNF- $\alpha$ levels but this did not result in an improved outcome. In contrast, IL-1 and MPO levels were even increased upon ASIS and APC administration using a 1-hr ischemia period. Furthermore, increased MPO levels were detected after $24 \mathrm{hr}$ of reperfusion compared to $2 \mathrm{hr}$. A lack of decrease in
IL-6 levels by ASIS or APC can contribute to a lack in protective effects as mice deficient in IL-6 showed reduced renal injury as determined by creatinine levels and histological scoring in a study for ischemic renal failure [32]. Furthermore, MPO is shown to be a critical factor in determining renal ischemic injury as $\mathrm{MPO}^{-/-}$had less renal function loss upon ischemia [33]. Therefore, we postulate that the lack of protection by APC and ASIS is in part related to the absence of any clear anti-inflammatory effect. It should be noted that also in vitro, several pro-inflammatory effects of APC have been noted [34] and it seems likely that many additional factors beyond those currently studied, modulate the net responses to APC and ASIS in vivo, including doses, timing, and experimental model used. In this regard it is of importance to keep in mind that in the clinical setting, APC is only protective in patients with advanced sepsis and not in less diseased persons where it may even be detrimental [7]. For ASIS or antiTF treatment, clinical studies in sepsis and other conditions remain equivocal.

To explain the results found in this study, several differences among the experimental models used in previous studies should be taken into account. An overview of the different mouse or rat models of I/R injury in which anticoagulants are used as an intervention is given in Table 1.

One important factor may be that our study is the only one in which one kidney was clamped and where, after the ischemia phase, the contralateral kidney was removed. We chose this model because it better represents the clinical situation in which a transplanted kidney in a functionally anephric individual, is failing due to I/R injury. Furthermore, this model was used in several studies showing beneficial outcomes [33, $35,36]$. When a kidney sparing effect of the interventions remained absent, we infused a higher dose of APC at a different time point earlier in the ischemia phase. Again, however, no beneficial effect on renal I/R injury was observed.

The study by Frank et al. [29] also did not reveal an effect of fondaparinux until after $48 \mathrm{hr}$ of reperfusion but a reperfusion time longer than $24 \mathrm{hr}$ was not used in our study

Table 1. Overview of distinct studies on renal $I / R$ injury with anticoagulant intervention.

\begin{tabular}{|c|c|c|c|c|}
\hline Study & Renal clamping & I/R time & Intervention & Outcome \\
\hline $\begin{array}{l}\text { Loubele et al. (this } \\
\text { study) }\end{array}$ & $\begin{array}{l}\text { Clamping left kidney, right } \\
\text { nephrectomy after I }\end{array}$ & $\begin{array}{l}40 \text { or } 60 \mathrm{~min} I \\
2 \text { or } 24 \mathrm{hrs} \mathrm{R}\end{array}$ & $\begin{array}{l}\text { Human ASIS or mouse APC } \\
\text { I.v. just prior to declamping } \\
\text { and } 5 \text { min after declamping }\end{array}$ & No effect \\
\hline Frank et al. [29] & $\begin{array}{l}\text { Clamping left and right } \\
\text { kidney }\end{array}$ & $\begin{array}{l}20,25, \text { or } 30 \text { min I } \\
24 \text { or } 48 \text { hrs } R\end{array}$ & $\begin{array}{l}\text { Fondaparinux } \\
\text { I.p. just prior to declamping } \\
\text { and } 5 \text { min after declamping }\end{array}$ & Effect after $48 \mathrm{hrs} \mathrm{R}$ \\
\hline Mizutani et al. [14] & $\begin{array}{l}\text { Left nephrectomy before I } \\
\text { Clamping right kidney }\end{array}$ & $\begin{array}{l}60 \min I \\
3,6,12, \text { or } 24 \text { hrs } R\end{array}$ & $\begin{array}{l}\text { Human APC } \\
\text { I.v. } 30 \text { min before declamping }\end{array}$ & Protective effect \\
\hline Mizutani et al. [18] & $\begin{array}{l}\text { Left nephrectomy before I } \\
\text { Clamping right kidney }\end{array}$ & $\begin{array}{l}45 \min \mathrm{I} \\
3,6,12,24 \text {, or } 48 \mathrm{hrs} R\end{array}$ & $\begin{array}{l}\text { Antithrombin } \\
\text { I.v. } 30 \text { min before declamping }\end{array}$ & Protective effect \\
\hline Nitescu et al. [19] & $\begin{array}{l}\text { Clamping left and right } \\
\text { kidney }\end{array}$ & $\begin{array}{l}35 \min \mathrm{I} \\
24 \mathrm{hrs} \mathrm{R}\end{array}$ & $\begin{array}{l}\text { Melagatran } \\
\text { Continuous injection }\end{array}$ & No effect \\
\hline
\end{tabular}


due to decreasing survival rates that were observed in this study when the reperfusion time was prolonged.

In conclusion, we did not reveal an effect of the anticoagulants APC or ASIS on renal I/R injury. These results are not in accordance with data from previous studies, showing a protective effect of APC, or functional TF deficiency, on renal I/R injury $[14,26]$. In the absence of major differences in doses used and timing of administration we assume that differences between the models used (clamping one or two kidneys, or the removal of one kidney before the collateral kidney was clamped) are major confounders of the effects of the anticoagulant proteins. The results of this study suggests that more research is needed to determine whether the use of specific anticoagulants potentially be of clinical benefit in the protection against renal I/R injury.

\section{ACKNOWLEDGMENTS}

We kindly acknowledge Dr. C.T. Esmon (Howard Hughes Medical Institute, Oklahoma City, Oklahoma, USA) and Dr. L.C. Petersen (Novo Nordisk A/S, Måløv and Bagsværd, Denmark) for providing us with mouse APC and human ASIS. This study was supported by the Netherlands Heart Foundation [grant no. 2003-B065].

\section{REFERENCES}

[1] Thadhani R, Pascual M, Bonventre JV. Acute renal failure. N Engl J Med. 1996;334(22):1448-60. doi:10.1056/NEJM19960 5303342207

[2] Thurman JM. Triggers of inflammation after renal ischemia/ reperfusion. Clin Immunol. 2007;123(1):7-13. doi:10.1016/j. clim.2006.09.008

[3] Dagher PC. Apoptosis in ischemic renal injury: Roles of GTP depletion and p53. Kidney Int. 2004;66:506-9. doi:10.1111/ j.1523-1755.2004.761_7.x

[4] Daemen MA, de Vries B, Buurman WA. Apoptosis and inflammation in renal reperfusion injury. Transplantation. 2002;73 (11):1693-700. doi:10.1097/00007890-200206150-00001

[5] Daemen MA, de Vries B, Wolfs TG, Buurman WA. Apoptosis and chemokine induction after renal ischemia-reperfusion. Transplantation. 2001;71(7):1007-11. doi:10.1097/00007890200104150-00032

[6] Daemen MA, Denecker G, van't Veer C, Wolfs TGAM, Vandenabeele P, Buurman WA. Activated caspase- 1 is not a central mediator of inflammation in the course of ischemiareperfusion. Transplantation. 2001;71(6):778-84. doi:10.1097/ 00007890-200103270-00016

[7] Bernard GR, Vincent JL, Laterre PF, Larosa SP, Dhainaut JF, Lopez-Rodriguez A, Steingrub JS, Garber GE, Helterbrand JD, et al. Efficacy and safety of recombinant human activated protein C for severe sepsis. N Engl J Med. 2001;344(10):699709. doi:10.1056/NEJM200103083441001

[8] Mosnier LO, Zlokovic BV, Griffin JH. The cytoprotective protein C pathway. Blood. 2007;109(8):3161-72. doi:10.1182/blood2006-09-003004

[9] Shibata M, Kumar SR, Amar A, Fernandez JA, Hofman F, Griffin $\mathrm{JH}$, Zlokovic BV. Anti-inflammatory, antithrombotic, and neuroprotective effects of activated protein $\mathrm{C}$ in a murine model of focal ischemic stroke. Circulation. 2001;103(13):1799-805. doi:10.1161/01.CIR.103.13.1799
[10] Zlokovic BV, Zhang C, Liu D, Griffin JH, Chopp M. Functional recovery after embolic stroke in rodents by activated protein $\mathrm{C}$. Ann Neurol. 2005;58(3):474-7. doi:10.1002/ana.20602

[11] Slofstra SH, Groot AP, Maris NA, Reitsma PH, Cate HT, Spek CA. Inhalation of activated protein $\mathrm{C}$ inhibits endotoxin-induced pulmonary inflammation in mice independent of neutrophil recruitment. Br J Pharmacol. 2006;149(6):740-6. doi:10.1038/ sj.bjp.0706915

[12] Hirose K, Okajima K, Taoka Y, Uchiba M, Tagami H, Nakano KY, Utoh J, Okabe $\mathrm{H}$, Kitamura N. Activated protein $\mathrm{C}$ reduces the ischemia/reperfusion-induced spinal cord injury in rats by inhibiting neutrophil activation. Ann Surg. 2000;232(2):272-80. doi:10.1097/00000658-200008000-00018

[13] Isermann B, Vinnikov IA, Madhusudhan T, Herzog S, Kashif M, Blautzik J, Corat MAF, Zeier M, Blessing E, Oh J, et al. Activated protein $\mathrm{C}$ protects against diabetic nephropathy by inhibiting endothelial and podocyte apoptosis. Nat Med. 2007;13(11): 1349-58. doi:10.1038/nm1667

[14] Mizutani A, Okajima K, Uchiba M, Noguchi T. Activated protein $\mathrm{C}$ reduces ischemia/reperfusion-induced renal injury in rats by inhibiting leukocyte activation. Blood. 2000;95:3781-87. doi:10.1182/blood-2013-03-493585

[15] Golino P, Ragni M, Cirillo P, Scognamiglio A, Ravera A, Buono C, Guarino A, Piro O, Lambiase C, Botticella F, et al. Recombinant human, active site-blocked factor VIIa reduces infarct size and no-reflow phenomenon in rabbits. Am J Physiol Heart Circ Physiol. 2000;278:H1507-16.

[16] Loubele ST, Spek CA, Leenders P, Oerle RV, Aberson HL, Van Der Voort D, Hamulyák K, Petersen LC, Spronk HMH, Ten Cate $\mathrm{H}$. Active site inhibited factor VIIa attenuates myocardial ischemia/reperfusion injury in mice. J Thromb Haemost. 2008; 7(2):290-8. doi:10.1111/j.1538-7836.2008.03232.x

[17] Frank RD, Holscher T, Schabbauer G, Tencati M, Pawlinski R, Weitz JI, Mackman N. A non-anticoagulant synthetic pentasaccharide reduces inflammation in a murine model of kidney ischemia-reperfusion injury. Thromb Haemost. 2006;96:802-6. doi:10.1160/th06-07-0418

[18] Mizutani A, Okajima K, Uchiba M, Isobe H, Harada N, Mizutani S, Noguchi T. Antithrombin reduces ischemia/reperfusion-induced renal injury in rats by inhibiting leukocyte activation through promotion of prostacyclin production. Blood. 2003;101(8): 3029-36. doi:10.1182/blood-2002-08-2406

[19] Nitescu N, Grimberg E, Ricksten SE, Marcussen N, Guron G. Thrombin inhibition with melagatran does not attenuate renal ischaemia-reperfusion injury in rats. Nephrol Dial Transplant. 2007;22(8):2149-55. doi:10.1093/ndt/gfm158

[20] Cheng T, Liu D, Griffin JH, Fernández JA, Castellino F, Rosen ED, Fukudome K, Zlokovic BV. Activated protein C blocks p53mediated apoptosis in ischemic human brain endothelium and is neuroprotective. Nat Med. 2003;9(3):338-42. doi:10.1038/ nm826

[21] Sommeijer DW, van Oerle R, Reitsma PH, Timmerman JJ, Meijers JC, Spronk HM, Ten Cate H. Analysis of blood coagulation in mice: Pre-analytical conditions and evaluation of a home-made assay for thrombin-antithrombin complexes. Thrombosis J. 2005;3(1):12. doi:10.1186/1477-9560-3-12

[22] Leemans JC, Stokman G, Claessen N, Rouschop KM, Teske GJD, Kirschning CJ, Akira S, Van Der Poll T, Weening JJ, Florquin S. Renal-associated TLR2 mediates ischemia/reperfusion injury in the kidney. J Clin Invest. 2005;115(10):2894-903. doi:10.1172/ JCI22832

[23] Spek CA, Verbon A, Aberson H, Pribble JP, Mcelgunn CJ, Turner T, Axtelle T, Schouten J, Poll TVD, Reitsma PH. Treatment with an anti-CD14 monoclonal antibody delays and inhibits lipopolysaccharide-induced gene expression in humans in vivo. 
J Clin Immunol. 2003;23(2):132-40. doi:10.1023/A:10225289 12387

[24] Wu H, Chen G, Wyburn KR, Bertolino P, Yin J, Eris JM, Alexander SI, Sharland AF, Chadban SJ. TLR4 activation mediates kidney ischemia/reperfusion injury. J Clin Invest. 2007;117(10):2847-59. doi:10.1172/JCI31008

[25] Enestrom S, Druid H, Rammer L. Fibrin deposition in the kidney in post-ischaemic renal damage. Br J Exp Pathol. 1988;69: 387-94.

[26] Sevastos J, Kennedy SE, Davis DR, Sam M, Peake PW, Charlesworth JA, Mackman N, Erlich JH. Tissue factor deficiency and par-1 deficiency are protective against renal ischemia reperfusion injury. Blood. 2007;109(2):577-83. doi:10.1182/ blood-2006-03-008870

[27] Coughlin SR. Protease-activated receptors in hemostasis, thrombosis and vascular biology. J Thromb Haemost. 2005;3:180014. doi:10.1111/j.1538-7836.2005.01377.x

[28] Rondeau E, Vigneau C, Berrou J. Role of thrombin receptors in the kidney: lessons from par1 knock-out mice. Nephrol Dial Transplant. 2001;16(8):1529-31. doi:10.1093/ndt/16.8.1529

[29] Frank RD, Schabbauer G, Holscher T, Tencati M, Pawlinski R, Mackman N. The synthetic pentasaccharide fondaparinux reduces coagulation, inflammation and neutrophil accumulation in kidney ischemia-reperfusion injury. J Thromb Haemost. 2005;3(3):531-40. doi:10.1111/j.1538-7836.2005.01188.x

[30] Turunen AJ, Fernandez JA, Lindgren L, Salmela KT, Kyllonen LE, Makisalo H, Griffin JH, Siitonen SM, Petaja J, Pesonen EJ. Activated protein $\mathrm{C}$ reduces graft neutrophil activation in clinical renal transplantation. Am J Transplant. 2005;5(9):2204-12. doi:10.1111/j.1600-6143.2005.00994.x

[31] Loubele STBG, Spek CA, Leenders P, van Oerle R, Aberson HL, Hamulyak K, Ferrell G, Esmon CT, Spronk HMH, Ten Cate H. Activated protein $\mathrm{C}$ protects against myocardial ischemia/ reperfusion injury via inhibition of apoptosis and inflammation. Arterioscler Thromb Vasc Biol. 2009; 29(7):1087-92. doi:10.1161/ATVBAHA.109.188656

[32] Kielar ML, John R, Bennett M, Richardson JA, Shelton JM, Chen L, Jeyarajah DR, Zhou XJ, Zhou H, Chiquett B, Nagami GT, Lu CY. Maladaptive role of IL-6 in ischemic acute renal failure. J Am Soc Nephrol. 2005;16(11):3315-25. doi:10.1681/ASN.20030 90757

[33] Matthijsen RA, Huugen D, Hoebers NT, de Vries B, PeutzKootstra CJ, Aratani Y, Daha MR, Tervaert JWC, Buurman WA, Heeringa P. Myeloperoxidase is critically involved in the induction of organ damage after renal ischemia reperfusion. Am J Pathol. 2007;171(6):1743-52. doi:10.2353/ajpath.2007.070184
[34] Baltch AL, Bopp LH, Ritz WJ, Michelsen PB, Yan SB, Um S, Smith $\mathrm{RP}$. Effect of recombinant human activated protein $\mathrm{C}$ on the bactericidal activity of human monocytes and modulation of proinflammatory cytokines in the presence of antimicrobial agents. J Antimicrob Chemother. 2007;59(6):1177-81. doi:10.1093/ $\mathrm{jac} / \mathrm{dkm} 080$

[35] Daemen MA, van't Veer C, Denecker G, Heemskerk VH, Wolfs TGAM, Clauss M, Vandenabeele P, Buurman WA. Inhibition of apoptosis induced by ischemia-reperfusion prevents inflammation. J Clin Invest. 1999;104(5):541-49. doi:10.1172/JCI6974

[36] Daemen MA, Heemskerk VH, van't Veer C, Denecker G, Wolfs TGAM, Vandenabeele P, Buurman WA. Functional protection by acute phase proteins alpha(1)-acid glycoprotein and alpha(1)antitrypsin against ischemia/reperfusion injury by preventing apoptosis and inflammation. Circulation. 2000;102(12):1420 1426. doi:10.1161/01.CIR.102.12.1420

\section{Competing Interests}

The authors declare no competing interests.

\section{Publishing Notes}

(C) 2014 S.T.B.G. Loubele et al. This work has been published open access under Creative Commons Attribution License CC BY 4.0, which permits unrestricted use, distribution, and reproduction in any medium, provided the original work is properly cited. Conditions, terms of use and publishing policy can be found at www.scienceopen.com.

Please note that this article may not have been peer reviewed yet and is under continuous post-publication peer review. For the current reviewing status please click here or scan the QR code on the right.

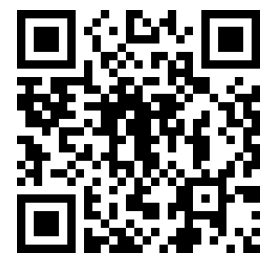

\section{scienceOPEN.com}

